\title{
MODIFICAÇÕES NO CÓDIGO CIVIL REALIZADAS PELA MEDIDA PROVISÓRIA № 881/2019 DO GOVERNO FEDERAL
}

\section{CIVIL CODE MODIFICATIONS CARRIED OUT BY FEDERAL PROVISIONAL MEASURE No. 881/2019}

LUCAS AMARAL DASSAN Mestrando em Direito Empresarial e Cidadania no Centro Universitário Curitiba UNICURITIBA. Curitiba - PR. Possui graduação em Direito pelo Centro Universitário Curitiba (2006). Detém especialização pela PUC/PR em Processo Civil Contemporâneo (2008) e, na mesma universidade, especialização em Direito Civil e Empresarial (2014).email: lucasdassan@hotmail.com

RESUMO

A pesquisa correlata tem como finalidade descrever e analisar as modificações concretizadas pela Medida Provisória o 881/2019 do Governo Federal, concernentes a alterações efetivadas no Código Civil, especificamente quanto aos institutos vinculados à desconsideração da personalidade jurídica, bem como à formação e interpretação dos contratos empresariais e não empresariais. A Medida Provisória ํo 881/2019 estabelece um novo balizamento para institutos jurídicos relacionados ao mercado, trazendo verdadeira declaração dos direitos de liberdade econômica, imperando princípios do liberalismo econômico e da intervenção mínima do Estado no mercado. Por este viés, concretiza inovações que dizem respeito a determinadas normas, constituindo e modificando regras e princípios que estão concatenados à livre iniciativa, à sistemática contratual, ao direito urbano, bem como aos impactos regulatórios. Da análise das regras 


\section{Personalidade Acadêmica Homenageada:}

Raymundo Juliano Feitosa (Universidade Federal do Rio Grande do Norte - UFRN)

promulgadas, abrem-se questões sobre as referidas modificações: no que se refere às normas de direito civil e de direito empresarial, quais as mudanças concretizadas quanto aos temas envolvendo a desconsideração da personalidade jurídica e a formação e a interpretação dos contratos empresariais? O presente trabalho tem por objetivo a descrição e a análise das transformações geradas em face dos correlatos institutos. Por este caminho, procurar-se-á estabelecer as linhas gerais e os princípios e valores apresentados pela Medida Provisória ํo 881/2019. De forma subsequente, buscará ser descrita cada modificação concernente aos temas indicados, realizando breve análise sobre as referidas transformações. Justifica-se a importância do estudo, pois estampam inovações no ordenamento jurídico pátrio, tanto de cunho principiológico como concernentes às regras, sendo que impactarão em uma infinidade de negócios jurídicos, envolvendo quantidades significativas de entidades, empresas e indivíduos. As alterações se revelam significativas do ponto de vista econômico; de outra forma, sustenta-se a seriedade da análise para que se verifique as eventuais consequências das mutações correlatas. $O$ trabalho utiliza a metodologia dedutiva, descritiva e também analítica, bem como a hermenêutica para abordar a análise normativa, as eventuais definições doutrinárias já existentes e as possíveis vertentes paradigmáticas. Em conclusão, até o presente momento, é possível observar que as referidas modificações normativas trarão maior aproximação às diretrizes do liberalismo econômico, da autonomia privada e da intervenção mínima do Estado no mercado, resgatando-se, especialmente no que concerne os ramos do direito empresarial e comercial, princípios próprios e autônomos que Ihes são conectados e que haviam sido distanciados da realidade em razão da unificação do direito empresarial com o direito civil através do anterior advento do Código Civil brasileiro de 2002.

PALAVRAS-CHAVE: MP 881/2019; Liberalismo Econômico e Intervenção Mínima; Código Civil; Desconsideração da Personalidade Jurídica; Formação e Interpretação dos Contratos. 
Personalidade Acadêmica Homenageada:

Raymundo Juliano Feitosa (Universidade Federal do Rio Grande do Norte - UFRN)

\section{REFERÊNCIAS}

BERTOLDI, Marcelo M.; RIBEIRO, Marcia Carla Pereira. Curso avançado de direito comercial. 10. ed. São Paulo: Revista dos Tribunais, 2016.

BRASIL. Lei no 10.406, de 10 de jan de 2002. Institui o Código Civil. Brasília, DF, jan 2002.

Medida Provisória no 881, de 30 de abr de 2019. Institui a Declaração de Direitos de Liberdade Econômica, estabelece garantias de livre mercado, análise de impacto regulatório, e dá outras providências. Brasília, DF, abr 2019.

COELHO, Fábio Ulhoa, Curso de direito empresarial. V. 3. 17. ed. São Paulo: Revista dos Tribunais, 2016.

TOMAZETTE, Marlon. Curso de direito empresarial. V. 1. 3. ed. São Paulo: Atlas, 2014. 